\title{
ADMITTING MENTAL HEALTH EVIDENCE TO IMPEACH THE CREDIBILITY OF A SEXUAL ASSAULT COMPLAINANT
}

\author{
TESS WILKINSON-RYAN ${ }^{\dagger}$ \\ INTRODUCTION
}

The 1970 edition of Wigmore on Evidence offers the proposition that every female complainant in a rape prosecution should be subject to a psychiatric examination and echoes turn-of-the century psychoanalysts in its explanation: "The unchaste (let us call it) mentality finds incidental but direct expression in the narration of imaginary sex incidents of which the narrator is the heroine or victim." In other words, some women falsely accuse men of rape because, either intentionally or inadvertently, they have confused a sexual fantasy with a violent crime.

The focus of this Comment, and the focus of considerable controversy and difficulty in rape trials, is evidentiary procedure when the defendant claims that the complainant consented to the intercourse. Putting aside the philosophical problem of defining consent, ${ }^{2}$ in the absence of physical injuries the only relevant evidence of the crime will be testimony from the defendant and the prosecutrix. ${ }^{3}$ Recent reforms have attempted to address this situation. Federal Rule of Evidence 413 , for example, permits prosecutors to introduce a defen-

${ }^{\dagger}$ J.D. Candidate, 2005, University of Pennsylvania Law School.

3A John Henry Wigmore, Evidence in Trials at COMmon LAW § 924a, at 736 (James H. Chadbourn ed., rev. vol. 1970). In 1907, Freud posited that every fantasy is a wish and that women in particular are subject to erotic fantasies: "The motive forces of phantasies are unsatisfied wishes, and every single phantasy is the fulfilment of a wish, a correction of unsatisfying reality.... In young women the erotic wishes predominate almost exclusively, for their ambition is as a rule absorbed by erotic trends." SIGMUND Freud, Creative Writers and Day-Dreaming, in ThE Freud REAdER 436, 439 (Peter Gay ed., 1989).

2 See, e.g., Stephen J. Schulhofer, Unwanted Sex: The Culture of InTIMIDATION AND THE FAILURE OF LAW 254-73 (1998) (discussing the legal and cultural implications of construing consent in different ways).

${ }^{3}$ See David P. Bryden, Redefining Rape, 3 Buff. CrIM. L. REv. 317, 336 (2000) (" $[\mathrm{I}] \mathrm{n}$ acquaintance-rape trials, corroborative evidence is often lacking; it is often hard to reconstruct precisely what the defendant did, let alone his intentions." (footnote omitted)). 
dant's history of sex crimes. ${ }^{4}$ This Comment examines the evidentiary tools available to the defendant to impeach the testimony of the complainant. The defendant is protected by the Sixth Amendment's Confrontation Clause, ${ }^{5}$ but this protection has been further defined, and some would say limited, by rape shield legislation. ${ }^{6}$ Rule 412 , the federal rape shield statute, broadly reflects the rejection of a system that conflated a woman's chastity with her credibility. ${ }^{7}$ With limited exceptions, it excludes evidence of a complainant's sexual history in a sexual assault case. And, of course, any evidence against her will be subject to the normal rules of relevancy and prejudice.

These rules, however, leave at least one large gap. In most states, neither the rape shield law, the other rules of evidence, nor the case law set out comprehensive guidelines for the admissibility of evidence of the complainant's mental health. ${ }^{8}$ Although no jurisdiction follows Wigmore's lead in mandating psychiatric examinations for every accuser, defendants may still request a review of a complainant's mental health history, a mental examination, or cross-examination as to a history of psychological problems. ${ }^{9}$

${ }^{4}$ See FED. R. EvID. 413(a) ("In a criminal case in which the defendant is accused of an offense of sexual assault, evidence of the defendant's commission of another offense or offenses of sexual assault is admissible, and may be considered for its bearing on any matter to which it is relevant."). For a feminist critique of Rule 413, see Aviva Orenstein, No Bad Men!: A Feminist Analysis of Character Evidence in Rape Trials, 49 HASTINGS L.J. 663, 690-97 (1998) (proposing that rape trial evidence procedure perpetuates stereotypes about aggressors and victims).

${ }^{5}$ U.S. CONST. amend. VI ("In all criminal prosecutions, the accused shall enjoy the right ... to be confronted with the witnesses against him ....").

${ }^{6}$ See, e.g., J. Alexander Tanford \& Anthony J. Bocchino, Rape Victim Shield Laws and the Sixth Amendment, 128 U. PA. L. REV. 544, 589-90 (1980) (arguing that rape shield laws should be struck down if they interfere excessively with the defendant's Sixth Amendment rights).

${ }^{7}$ See FED. R. EVID. 412 ("The following evidence is not admissible in any civil or criminal proceeding involving alleged sexual misconduct... (1) Evidence offered to prove that any alleged victim engaged in other sexual behavior... (2) Evidence offered to prove any alleged victim's sexual predisposition."); CASSIA SPOHN \& JULIE HORNEY, RAPE LAW REFORM: A GRASSROOTS REVOLUTION AND ITS IMPACT 25-27 (1992) (noting that the federal government and most states had passed rape shield legislation by 1985).

${ }^{8}$ For an interesting discussion of a defense strategy in the absence of prohibitions on discovery of mental health records, see Jeffrey Toobin, The Consent Defense, NEW YORKER, Sept. 1, 2003, at 40, 44, 87.

${ }^{9}$ See infra Part I (discussing current law that permits this evidence); infra Part II (discussing specific states' approaches). 
In this Comment, I argue that most jurisdictions are overly permissive in admitting evidence of the accuser's psychiatric make-up and history. Because many courts implicitly rely on outdated and inaccurate conceptions of psychiatric practice, it is too easy for defendants to introduce evidence that has no logical bearing on the complainant's credibility but will nonetheless prejudice the jury against her. This is not an argument about the complainant's right to privacy, but rather an argument about relevance and prejudice.

The introduction of psychiatric testimony intended to impeach the complainant's credibility can serve as an end-run around the rape shield laws; it contributes little relevant evidence, but humiliates the accuser and prejudices the jury against her. In some instances, expert testimony on the complainant's mental health may become an interrogation of the complainant's propensity for dishonesty. ${ }^{10}$ Like evidence of sexual promiscuity, an accusation of mental illness has the power to invoke a gender-specific stigma of an unstable or manipulative accuser. Worse, questions about an accuser's mental health may implicitly conjure up stereotypes of female sexual behavior: female psychopathology has long been specifically linked to female sexuality in general and promiscuity in particular. ${ }^{11}$

In Part I of this Comment, I present the current state of the law and outline the most common methods of introducing psychiatric evidence about an alleged rape victim, namely the review of counseling records, court-ordered psychiatric examination, and crossexamination of the alleged victim. In Part II, I survey different state approaches and examine those that are both typical and unusual.

In Part III, I argue that most psychological evidence should be inadmissible because its relevance is substantially outweighed by its prejudicial effects. Psychology may have entered popular culture in some shallow respects, but it is often misunderstood by courts and juries alike. In order to make a considered decision as to admissibility (by the judge) or guilt (by the jury), a thorough understanding of the alleged psychopathology is crucial-there is an enormous difference, in terms of cognitive functioning, between dysthymia, a mild depres-

\footnotetext{
${ }^{10}$ See, e.g., People v. Brown, 777 N.Y.S.2d 508, 510 (App. Div.) (allowing crossexamination of a prosecution's expert on the complainant's ability to fabricate lies), leave to appeal denied, 817 N.E.2d 827 (N.Y. 2004).

${ }^{11}$ See Mark S. MicAle, APProAChing Hysteria: DiseASE AND ITS INTERPRETATIONS 191 (1995) (describing the conflation of hysteria and nymphomania in the nineteenth century).
} 
sion, and paranoid schizophrenia, a psychotic disorder. ${ }^{12}$ There is even greater potential for jury confusion when evidence of actual psychotherapeutic treatment arises, in which the norms of a therapistpatient relationship, the theoretical orientation of the therapist, ${ }^{13}$ and the strictures of insurance guidelines ${ }^{14}$ may create a record that looks much more damning to a lay jury than it would to another therapist. Furthermore, psychiatry is an unusually controversial science and many of its methods are notoriously unreliable. ${ }^{15}$ Finally, it can be unclear exactly how a jury is meant to use psychiatric testimony or mental health records, and a judge's instructions may simply be inadequate to confine their effect.

In Part IV, I discuss three common types of psychological evidence that defendants seek to admit: pathological lying, suicide threats, and post-traumatic stress disorder. Although all three labels are seemingly familiar to laypersons, it is this false familiarity that makes this evidence dangerously prejudicial.

Admitting evidence of a complainant's psychiatric history can create prejudice and confusion for the court and jury and humiliate the prosecutrix. In order to adjudicate the admissibility of mental health evidence, courts should identify a specific and scientifically legitimate relevance to the complainant's credibility. This should be balanced against the potentially misleading and confusing effect that the information will have on the fact-finding process. This reformed process likely would result in a reduction in admitted psychiatric evidence in rape trials, but also a greater adherence to the rules of evidence. Without this necessary reform, states continue to rely on a hazy mix of laws and evidentiary theories that may allow the use of a rape com-

${ }^{12}$ See Task Force on DSM-IV, Am. Psychiatric Ass'N, Diagnostic and StaTISTICAL MANUAL OF MENTAL DisORDERS 313-14, 376-81 (4th ed., text rev. 2000) [hereinafter DSM-IV-TR] (listing no cognitive deficits in the diagnosis of dysthymia, as compared to schizophrenia, paranoid type, whose symptoms include delusions and hallucinations).

${ }^{13}$ See, e.g., The American Psychiatric Publishing Textbook of Clinical PSYCHIATRY pt. III (Robert E. Hales \& Stuart C. Yudofksy eds., 4th ed. 2003) [hereinafter TeXtBoOK OF Clinical Psychiatry] (describing different approaches to psychotherapeutic treatment, including cognitive-behavioral and psychodynamic).

${ }^{14}$ See, e.g., James E. Sabin \& Norman Daniels, Determining "Medical Necessity" in Mental Health Practice, Hastings CenTER ReP., Nov.-Dec. 1994, at 5 (describing the disjunction between insurance coverage and diagnostic practice in psychotherapy).

${ }^{15}$ For a particularly apt example of controversial psychology, see Daniel Lyons, Sex, God E Greed: Battle of the Shrinks, FORBES, June 9, 2003, at 72. 
plainant's mental health history to showcase her unreliability as a witness.

\section{FoundATIONS OF CURRENT LAW}

\section{A. Rape Shield Laws}

Every state has enacted some form of a rape shield law, a law limiting the admissibility of evidence regarding the complainant's sexual history. ${ }^{16}$ Federal Rule of Evidence 412 prohibits "[e]vidence offered to prove that [the] victim engaged in other sexual behavior" or evidence offered to prove a "sexual predisposition." ${ }^{17}$ Exceptions are allowed to prove that physical evidence (e.g., semen) was the result of intercourse with a person other than the defendant, or, in the case of a consent defense, to prove that the victim had in the past consented to and engaged in sex with the defendant. ${ }^{18}$

When considering the admissibility of mental health history evidence, many courts are especially concerned with the purpose of the rape shield statute. The Advisory Committee's Note to the 1994 amendment explains that

[t]he rule aims to safeguard the alleged victim against the invasion of privacy, potential embarrassment and sexual stereotyping that is associated with public disclosure of intimate sexual details and the infusion of sexual innuendo into the factfinding process. By affording victims protection in most instances, the rule also encourages victims of sexual misconduct to institute and to participate in legal proceedings against alleged offenders. ${ }^{19}$

Some courts have reasoned that a similar argument can be made for evidence of psychiatric, rather than sexual, history. ${ }^{20}$ The purpose

${ }^{16}$ See Stacy Futter \& Walter R. Mebane, Jr., The Effects of Rape Law Reform on Rape Case Processing, 16 BERKELEY WOMEN'S L.J. 72, 78-80 (2001) (taxonomizing the different types of rape law reforms enacted by the states).

${ }^{17}$ FED. R. EVID. 412(a).

${ }^{18}$ Id. $412(\mathrm{~b})$.

${ }^{19} I d .412$ advisory committee's note.

${ }^{20}$ See, e.g., People v. Espinoza, 116 Cal. Rptr. 2d 700, 718 (Ct. App. 2002) ("The distrust of complaining witnesses in sex offense cases that formed the foundation for [rulings permitting psychiatric examinations] was based on antiquated beliefs that have since been disproved and discarded [by b] oth the Legislature and the California Supreme Court ...."); see also State v. McHolland, 800 A.2d 667, 674 (Conn. App. Ct. 2002) (permitting the admission of psychiatric testimony after in camera review, but using the rape shield law as a framework for such evaluation). 
of the rape shield laws is to protect the prosecuting witnesses from probing, humiliating inquiries and thereby to encourage victims to come forward with their claims. Although the stigma attached to promiscuity is qualitatively different than that associated with psychopathology, the underlying principle justifying protection is the same. The defendant, not the complainant, is on trial; the focus of evidence should relate to the defendant's actions rather than to the complainant's character.

The Advisory Committee's Note to Rule 412 does not take an explicit position on the relevance of past sexual conduct to consent and credibility. We can assume that an "infusion of sexual innuendo into the fact finding process" ${ }^{\prime 21}$ is undesirable because it is more prejudicial than relevant, but some states have nonetheless permitted evidence of past sexual conduct to be used to prove consent or to impeach credibility. ${ }^{22}$ A specific repudiation of the link between chastity and credibility-and even past consent with current consent-would be more analytically helpful to courts trying to analogize sexual conduct to mental health evidence.

\section{B. Court-Ordered Psychiatric Examinations}

Although the states differ in both subtle and substantive ways in their treatment of court-ordered psychiatric examinations of sex crime complainants, the touchstone for many analyses is the California Supreme Court's ruling in Ballard v. Superior Court. ${ }^{23}$ The Ballard court explained that the rationale supporting psychiatric examinations for sex crime complainants is the possibility that a conviction may be sustained on the uncorroborated testimony of the victim: "This concern is stimulated by the possibility that a believable complaining witness, who suffers from an emotional condition inducing her belief that she has been subjected to a sexual offense, may charge some male with that offense." ${ }^{24}$ Citing "prominent psychiatrists," the court noted that these accusers may be confused by "a mental condition that transforms into fantasy a wishful biological urge." ${ }^{25}$ Califor-

${ }^{21}$ FED R. EVID. 412 advisory committee's note.

${ }^{22}$ See SPOHN \& HoRney, supra note 7, at 27 (noting that Washington and Nevada allow evidence to show consent and that California permits sexual history evidence to impeach credibility).

23410 P.2d 838 (Cal. 1966), superseded by CAL. PENAL CODE $§ 1112$ (West 2004).

${ }^{24}$ Ballard, 410 P.2d at 846.

${ }^{25} I d$. 
nia evidence rules did not permit psychiatric testimony for the purposes of impeaching a witness in non-sex crime cases. ${ }^{26}$ The court pointed out that " $[\mathrm{t}]$ he proposition that a prosecution witness may be impeached only in the manner and for purposes provided in the code does not enjoy rigid application in sex violation cases. In that area the courts have established more liberal rules of impeachment...."27 Thus, the California Supreme Court ruled that it is within a trial court's discretion to order a mental examination in cases lacking substantial corroboration supporting the charge and when the defendant presents a compelling reason. ${ }^{28}$ If the complainant refuses the examination, the court noted, she should not be compelled, but the defense should be allowed to comment on the refusal. ${ }^{29}$ Although the California legislature overruled this decision in $1980,{ }^{30}$ the Ballard approach, granting discretion to the trial judge, remains the law in other jurisdictions. ${ }^{31}$

Some commentators have approved the Ballard approach as an appropriate balance of competing interests. ${ }^{32}$ Unfortunately, courts often misunderstand the interests at stake and balance the potential prejudice to the defendant with the intrusion into the complainant's privacy. ${ }^{33}$ Both the complaining witness and the court, however, have

${ }^{26} I d$.

27 Id. at 847 (citation omitted).

28 Id. at 849 .

${ }^{29} I d$.

30 See CAL. PENAL CoDE $§ 1112$ (West 2004) (forbidding courts from ordering psychiatric examinations of alleged victims in sex crime cases).

31 See, e.g., State v. Demos, 619 P.2d 968, 970 (Wash. 1980) (en banc) (citing Ballard and noting that "[t]he vast majority [of jurisdictions hold] that the trial court does have discretion to order a psychiatric examination of the complaining witness where a compelling reason is shown”); see also, e.g., State v. Wahrlich, 459 P.2d 727, 730 (Ariz. 1969) (en banc) (adopting the Ballard standard); State v. Kahinu, 498 P.2d 635, 642 (Haw. 1972) (same); State v. Filson, 613 P.2d 938, 942 (Idaho 1980) (same); State v. Robinson, No. 55972, 1992 WL 20269, at*10 \& n.2 (Mo. Ct. App. Feb. 11) (same), aff'd, 835 S.W.2d 303 (Mo. 1992) (en banc); State v. Ballard, 714 S.W.2d 284, 287 (Tenn. Crim. App. 1986) (same), aff'd, 855 S.W.2d 557 (Tenn. 1993); State v. Braxton, 580 P.2d 1116, 1118-19 (Wash. Ct. App. 1978) (same).

${ }^{32}$ See, e.g., Judith Greenberg, Note, Compulsory Psychological Examination in Sexual Offense Cases: Invasion of Privacy or Defendant's Right?, 58 FORDHAM L. REV. 1257, 1268 (1990) (" $[\mathrm{W}]$ here there is the danger of fabrication, a compulsory psychological examination of the prosecutrix is essential. The Ballard balancing analysis gives a court the flexibility to order a psychological examination of a prosecutrix in situations where the harm to the accused outweighs the harm to the prosecutrix.").

33 See id. at 1266-67 ("If undue prejudice [to the defendant] is found, the court will order a psychological examination. If, however, the intrusion into the prosecu- 
an even greater interest in excluding confusing, misleading, and prejudicial evidence. The Ballard test permits a psychiatric examination when the prosecution lacks corroborating evidence to support the charge of sexual assault. ${ }^{34}$ The lack of corroboration, without a legitimate indication of the complainant's psychiatric instability, has no logical bearing on the appropriateness of a psychiatric examination.

\section{Review of Psychiatric and Counseling Records}

In Pennsylvania v. Ritchie, the Supreme Court held that when a defendant seeks access to confidential records (e.g., medical, counseling, etc.), judicial in camera review is proper to determine the relevance and admissibility of the records. ${ }^{35}$ The Court's position attempted to balance the defendant's Sixth Amendment confrontation right with the complainant's right to privacy. The Court reasoned that the state's interest in the confidentiality of certain records is superseded by the defendant's right of confrontation, but that records should not be fully and immediately disclosed to defense counsel upon request. ${ }^{36}$ Although the defendant, Ritchie, was not specifically seeking to impeach the complaining witness-his daughter, whom he was accused of sexually abusing - by questioning her psychological stability, ${ }^{37}$ the ruling clearly bears on the right of defendants to use counseling records against complainants. Ritchie is often cited when prosecutors introduce evidence of rape trauma syndrome and the defense seeks access to post-incident records. ${ }^{38}$ The import of Ritchie is potentially even more complicated when defendants request pre-rape

trix's protected right of privacy is greater than the prejudice that will result to the defendant, the examination will not be ordered." (footnotes omitted)).

34 See Ballard, 410 P.2d at 849 (noting the importance of a psychiatric evaluation "if little or no corroboration supported the charge").

35480 U.S. 39, 61 (1987).

${ }^{36} I d$.

${ }^{37}$ Ritchie asserted that a review of his daughter's file with Children and Youth Services, the protective services agency, would lead him to unspecified exculpatory evidence and "witnesses in his favor." Id. at 55.

${ }^{38}$ See, e.g., Simon Bronitt \& Bernadette McSherry, The Use and Abuse of Counseling Records in Sexual Assault Trials: Reconstructing the "Rape Shield"?, 8 CRIM. L.F. 259, 263 (1997) (noting defense counsels' efforts to obtain post-rape counseling records for various impeachment purposes); Ellen M. Crowley, Note, In Camera Inspections of Privileged Records in Sexual Assault Trials: Balancing Defendants' Rights and State Interests Under Massachusetts's Bishop Test, 21 AM. J.L. \& MED. 131, 146-49 (1995) (discussing the Massachusetts approach to review of rape counselors' files). 
counseling records and judges alone determine which sections are relevant to the defense.

\section{STATE APPROACHES}

\section{A. Response to Pennsylvania v. Ritchie: Massachusetts}

The Ritchie decision has left room for state courts to establish their own respective systems of balancing the rights of defendants and complainants. Massachusetts has established a particularly careful scheme over the past ten years, beginning with its landmark decision in Commonwealth v. Bishop. ${ }^{39}$ In Bishop, the Massachusetts Supreme Judicial Court established a five-stage process to admit otherwise privileged counseling records. ${ }^{40}$ When a defendant requests access to a complainant's counseling records, the judge first determines whether or not the records are privileged under state law. ${ }^{41}$ If they are protected by a privilege (and most counseling records are privileged under the Massachusetts statute), ${ }^{42}$ the judge makes a relevancy determination of whether the defendant has shown "at least some factual basis which indicates how the privileged records are likely to be relevant to an issue in the case." ${ }^{, 3}$ If the judge is satisfied, she reviews the records in camera; if she finds relevant evidence, she then turns the records over to counsel for both sides in order to determine whether disclosure is necessary for a fair trial. ${ }^{44}$ The final step is entering the evidence into the trial record. ${ }^{45}$

Although this process initially appeared to be quite rigorous, the court found that a literal application of the Bishop test resulted in almost any claim by the defense yielding an in camera examination by the judge. ${ }^{46}$ The court amended the Bishop steps in Commonwealth $v$. Fuller, decided only three years later, by raising the defendant's bur-

${ }^{39} 617$ N.E.2d 990 (Mass. 1993).

${ }^{40} I d$. at $997-98$.

${ }^{41}$ In order to focus more clearly on the main argument about relevancy and prejudice, I will not discuss at any length the ramifications of different states' approaches to privilege or any conflicts between the United States Constitution and individual state constitutions.

${ }^{42}$ MASS. ANN. LAWS ch. 233, § 20B (Law. Co-op. 2000 \& Supp. 2004).

43 Bishop, 617 N.E.2d at 996-97.

${ }^{44} I d$. at 997.

${ }^{45} \mathrm{Id}$. at 998

${ }^{46}$ Commonwealth v. Fuller, 667 N.E.2d 847, 854 (Mass. 1996). 
den of demonstrating relevance. ${ }^{47}$ The court was particularly concerned with access to rape crisis counseling records. It found that the Bishop relevance requirement "almost invariably will result in an order requiring production of the records" because the nature of sexual assault counseling is that the victim discusses the incident at length. ${ }^{48}$ The current Bishop-Fuller process requires that a defendant's motion for in camera review of records be granted only when the motion demonstrates a "good faith, specific, and reasonable basis for believing that the records will contain exculpatory evidence which is relevant and material to the issue of the defendant's guilt." ${ }^{49}$ The court further explained that in order to be "material" the evidence must tend "to create a reasonable doubt that might not otherwise exist."

The Fuller decision still leaves questions about the admissibility of pre-rape psychiatric history. The more stringent standard appears to apply primarily to rape crisis counseling records. If a defendant knows anything about the complainant's history of mental illness or psychiatric treatment, it is not difficult to make a specific claim and to convince a court that it bears directly on credibility. Therefore, the question is whether Fuller overruled Commonwealth v. Baxter, a case in which a Massachusetts appellate court reversed and remanded a rape conviction because the trial judge had excluded evidence of psychiatric problems following a previous sexual assault. ${ }^{51}$ Defense counsel had sought to introduce the records to show confusion between the two incidents, claiming that the complainant's "flashbacks" bore on her ability to perceive and recollect the alleged rape. ${ }^{52}$

I argue that Fuller, in fact, clearly permits in camera review in such a case, providing explicitly that "credible information tending to suggest that the complainant has difficulty distinguishing fantasy from reality" warrants review of the records. ${ }^{53}$ However, it is actually during the in camera review, not during the initial relevancy determination, that a complainant has the best chance of convincing a court to exclude evidence of psychiatric history. In Commonwealth v. Westbrook, the defendant sought the counseling records of a complainant with a

${ }^{47}$ Id. at 855 .

${ }^{48} I d$. at 854

${ }^{49} I d$. at 855 .

${ }^{50} \mathrm{Id}$.

${ }^{51} 627$ N.E.2d 487, 490-92 (Mass. App. Ct. 1994).

${ }^{52}$ Id. at 490

${ }^{53} 667$ N.E.2d at 855 . 
history of depression, suicidal ideation, and auditory hallucinations. ${ }^{54}$ The appellate court affirmed the trial court's decision, after in camera review, to exclude psychiatric history evidence on the basis of relevancy. ${ }^{55}$ The opinion indicated a narrow focus on the relationship between the complainant's psychological conditions and her credibility. $^{56}$

As the Massachusetts Supreme Judicial Court recognized, "[i]n camera review, while less intrusive than public disclosure or disclosure to a defendant's attorney, is nonetheless a substantial invasion of the privacy of a complaining witness. ${ }^{, 57}$ And it does not seem clear that every judge would find a history of auditory hallucinations and treatment for previous sexual assault to be irrelevant. Nonetheless, the structure of the analysis seems right: the judge, not the jury, decides the relevance-narrowly defined-of the psychiatric history evidence. The most important step to help guarantee that this process functions properly is that courts have adequate knowledge of psychology and psychotherapy in order to contextualize and interpret the mental health records.

\section{B. Psychological Examinations of Complaining Witnesses: Statutory Responses}

\section{California}

Some state legislatures have addressed the problem of psychological examinations of complaining witnesses with straightforward legislation. The states in the Ninth Circuit have been particularly proactive, with Idaho, Alaska, and California all passing legislation limiting the power of courts to order mental examinations of crime victims. In this section, I will consider the statutory and derivative case law in California and argue that the state's apparently protective rule fails to

792 N.E.2d 696, 699 (Mass. App. Ct. 2003).

${ }^{55}$ Id. at $699-700$.

${ }^{56} I d$. at 700-01. The court noted that the victim's auditory hallucinations were actually suicidal ideations, not, for example, the voice of the defendant. Id. at 700 . The court distinguished the case from Commonwealth v. Fayerweather, 546 N.E.2d 345 (Mass. 1989), in which the "complainant claimed to hear the voice of the defendant telling her to do things." Westbrook, 792 N.E.2d at 700. The court also pointed out that possible confusion between a prior sexual assault and the immediate rape was unlikely given the complainant's clear testimony about the incident and the court's own agreement with the defendant's story as to most of the details. Id. at 701 .

${ }^{57}$ Fuller, 667 N.E.2d at 854. 
address the central problem of prejudice towards the complaining witness.

The California Supreme Court decided Ballard in 1966, carving out an exception to the rule against impeaching witnesses' credibility with psychiatric examinations. ${ }^{58}$ In 1980, however, the California legislature effectively overruled Ballard by enacting section 1112 of the Penal Code, entitled "Sexual assault prosecution; prohibition against psychiatric or psychological examination to test witness credibility." The section provides that no trial court may order any witness or victim in a sexual assault prosecution "to submit to a psychiatric or psychological examination for the purpose of assessing his or her credibility." ${ }^{\circ 0}$ It appears that the legislature was concerned about the protection of privacy rights and the problems of relevancy and prejudice. Subsequent cases considered the possible due process and confrontation clause objections to the statute, but found that " $[u]$ nder almost every rule of evidence, some arguably relevant material is excluded." " Thus, "[t] he confrontation and due process clauses do not prohibit a Legislature from determining that a certain class of evidence is generally unreliable or excessively prejudicial and barring its use altogether." ${ }^{2}$ The legislature's determination that evidence from psychiatric examinations in sexual assault prosecutions deserves blanket exclusion does not deprive defendants of costitutional rights.

In fact, however, the rejection of psychological examinations for victims of sex crimes has not precluded the admissibility of psychiatric testimony. Five years after section 1112 was passed, a California court of appeal clarified the relationship between section 1112 and a state constitutional provision mandating that no relevant evidence should be excluded in any criminal proceeding. ${ }^{63}$ In People v. Hagerman, the court ruled that " $[\mathrm{o}]$ rdering a psychiatric examination for a witness is not tantamount to ruling on the admissibility of any evidence which may be generated as a result of that examination." ${ }^{, 64}$ The court reasoned that the Ballard approach actually involves a two-step process:

${ }^{58}$ Ballard v. Superior Court, 410 P.2d 838 (Cal. 1966). See supra notes 23-31 and accompanying text for additional discussion of Ballard.

${ }_{59}$ CAL. PENAL Code $\$ 1112$ (West 2004).

${ }^{60} \mathrm{Id}$.

${ }^{61}$ People v. Fleming, 189 Cal. Rptr. 619, 621 (Ct. App. 1983).

62 Id.

63 CAL. CONST. art. I, \$ 28(d).

64213 Cal. Rptr. 286, 289 (Ct. App. 1985). 
first, the court determines "whether to order the [psychiatric] examination," and second, the court determines "the admissibility of the results of the examination." ${ }^{, 65}$ In Hagerman, the court ruled that section 1112 precludes a court from ordering the psychiatric examination of a complainant, which would create new evidence; this is distinct from whether existing psychiatric evidence should be admitted when relevant. ${ }^{66}$

Although California's statutory scheme appears to be highly protective of rape victims, the resulting rule of law still provides a method of impeachment to criminal defendants in sex crime prosecutions not usually available to other defendants. In People v. Herring, the court cited the general rule that although cross-examination about a witness's mental condition is usually permitted to impeach powers of perception or recollection, "generally, attempts to impeach a prosecution witness by expert psychiatric testimony have been rejected except in certain sex offense cases. ${ }^{, 67}$ Allowing the defense to present the testimony of a mental health expert who has not examined the complainant may protect the complainant's privacy and avoid the trauma of another retelling of her accusation, but the testimony presented is arguably of lesser value to a fact finder. Additionally, it is necessary to question whether a psychiatric examination is any more traumatic than listening to an unknown doctor testify about one's mental condition. It is important for courts to shield rape victims from the potentially traumatic effects of a prosecution and trial, but ultimately this is best accomplished by convicting the offender. It is the job of the jury to determine whether or not the complainant is a credible witness, and the expertise and authority of a mental health professional, or simply the taint of clinical diagnosis, may supplant a jury's own determinations.

\section{Illinois}

Unlike California, Illinois state law permits psychological examinations of witnesses and lacks proscriptions on impeachment by psychiatric testimony. ${ }^{68}$ Illinois has, however, passed a law specifically ex-

\footnotetext{
${ }^{65} I d$.

${ }^{66}$ Id. at 289-90. Hagerman held that section 1112 only overruled the first step of Ballard, but does not affect the second step concerning evidence admissibility.

${ }^{67} 25$ Cal. Rptr. 2d 213, 216 (Ct. App. 1993).

${ }^{68}$ See, e.g., People v. Kirchner, 743 N.E.2d 94, 112-13 (Ill. 2000) (upholding the decision of a trial court in a murder prosecution to permit in-depth cross-examination
} 
cluding rape victims from psychological examinations. ${ }^{69}$ In People $v$. Williams, an Illinois appellate court rejected an equal protection challenge to the statute by comparing the law to the clearly valid rape shield protections: "The constitutionality of the rape shield law has been upheld on the grounds that the statute was designed to encourage victims to report sexual assaults and to eliminate the cruel and abusive treatment of the victim at trial," and, because the two statutes are so similar, the prohibition on psychological examinations "can be said to accomplish [the same] legitimate governmental objective."70

However, the Illinois court, like the California courts, did not absolutely protect against the "cruel and abusive treatment of the victim at trial." In Williams, a particularly brutal case in which the complainant was paralyzed from the waist down after being raped and shot, the defendant was permitted to cross-examine the complainant and her doctors about the confusion and post-traumatic stress disorder that may have impaired her identification of the perpetrator. ${ }^{71}$ The Illinois legislature's efforts to protect complaining witnesses at trial is laudable, but the result in Illinois does not go far enough. To effectively protect complaining witnesses, evidence of psychological history should be excluded to the same degree that evidence of sexual history has been excluded via rape shield laws.

\section{North Carolina and Rape Fantasies}

North Carolina takes a unique and deeply problematic approach to the issue of psychological testimony in rape prosecutions. The North Carolina rape shield statute, like most rape shield provisions, allows for testimony about sexual history between the complainant and the defendant or evidence that would call into question the identity of the perpetrator. ${ }^{72}$ However, it also allows for "evidence of sex-

of a witness's psychiatric history but refusing the defense motion for a court-ordered psychological examination of the witness).

69725 ILl. COMP. STAT. 5/115-7.1 (2002) ("Court may not order mental examination of sex victim. Except where explicitly authorized ... no court may require or order a witness who is the victim of an alleged sex offense to submit to or undergo either a psychiatric or psychological examination.”).

${ }^{70} 581$ N.E.2d 228, 232 (Ill. App. Ct. 1991).

${ }^{71}$ See id. at 232-33 (holding that the defendant's confrontation rights were not denied when "the complaining witness and attending physician-surgeon were both present in court and available for cross-examination").

${ }^{72}$ N.C. GEN. STAT. § 8C-1, Rule 412(b) (1)-(2) (2003) (providing exceptions to the rule that evidence of the complainant's previous sexual behavior is irrelevant). 
ual behavior offered as the basis of expert psychological or psychiatric opinion that the complainant fantasized or invented the act or acts charged." ${ }^{73}$ This law makes questions about the complainant's capacity to confuse fantasy and reality, or to confabulate, a routine part of a rape trial. In order to introduce psychological testimony, the mere suggestion of psychological aberration is adequate. ${ }^{74}$ In State v. Heath, the court of appeals found that when the defense suggests that "the victim may have had a history of fantasizing or fabricating stories, expert psychological or psychiatric testimony should be admissible to show that the victim does or does not suffer from a mental condition suggestive of fabrication." 75

Prosecutors have found ways to employ this rule to their advantage, using the opening as a means of introducing evidence of a truthful character via expert witnesses, who may be most credible to a jury. In State $v$. Norfleet, the court of appeals upheld the prosecutor's direct examination of a clinical social worker, in which the prosecutor asked if she "had any concerns about [the complainant's] ability to distinguish between fantasy and reality." ${ }^{76}$ Not only was the question deemed proper, but the social worker's expansive encomium to the complainant's truthfulness was also permitted even though the defense counsel argued that the testimony "amounted to an expert opinion that [the] victim was telling the truth." 77 This apparent boon for prosecutors, however, is actually just a preemptive strike that is tacti-

${ }^{73} I d .412(\mathrm{~b})(4)$.

74335 S.E.2d 350, 354 (N.C. Ct. App. 1985).

${ }^{75}$ Id. The North Carolina Supreme Court ultimately reversed this case in State $v$. Heath, 341 S.E.2d 565 (N.C. 1986), on the ground that an expert witness may not be asked direct questions about the probability that the victim lied or that the victim is guilty. The supreme court's distinction between the rape shield's fantasy provision and the case at hand ultimately reaffirmed the confused-victim rationale behind fantasy testimony:

It is one thing to ask an expert in psychology or psychiatry whether a victim fantasizes, but it is another thing altogether to ask whether a witness has made up a story, or lied. One who fantasizes can honestly and subjectively believe in the reality of the fantasized-about occurrence, but "making up a story," or lying, denotes an affirmative or conscious intent to deceive, invent, or not tell the truth.

$I d$. at 568. That is, even though the case was reversed, the expert's testimony would have been permissible if it had only addressed whether the victim had a mental condition generally causing fantasies, rather than a history of lying.

${ }^{76}$ No. COA02-256, 2003 WL 21649165, at*3 (N.C. Ct. App. July 15, 2003).

${ }^{77}$ Id. But see Heath, 341 S.E.2d at 567-68 (holding that expert testimony on a "record of lying" is impermissible). 
cally necessary under a regime that places the victim's predisposition for confabulation at the crux of the trial. Yet, by introducing expert testimony as to the complainant's psychological health, the prosecution raises the issue for the jury and opens the door for the defense to cross-examine the expert and potentially introduce psychiatric testimony in rebuttal.

The North Carolina law is an explicit expression of distrust of women accusing men of rape. However, women's rape fantasies (a controversial subject in itself) ${ }^{78}$ are not necessarily-or even usuallylinked to real-world desires to be raped. ${ }^{79}$ The law contributes directly to the "no means yes" stereotype that encourages male aggression and female passivity. ${ }^{80}$ It seems particularly outrageous to imagine that women are unable to distinguish these fantasies from reality in such numbers that the issue required legislation. The North Carolina law is unusually invasive because the fantasy provision also allows evidence of sexual history if it pertains to sexual confabulation and fantasy. The existence of the statute implies an authoritative stance on a supposed female predisposition to confuse fantasies of rape with the real thing.

\section{Confusion And Prejudice}

In this section, I argue that evidence of a complainant's mental health history is more likely to contribute to confusion and prejudice than to shed light on the veracity of her account. Courts have been unsuccessful in dispelling the general stigma associated with mental health problems, explaining the intricacies of the therapist-patient relationship, and correcting the pervasive misunderstanding of the relationship between psychopathology and credibility.

\footnotetext{
78 See, e.g., Susan Brownmiller, Against Our Will: MEn, Women ANd RaPe 358-64 (1975) (arguing that rape fantasies are a myth perpetuated by Freudian psychiatrists and popular culture).

${ }^{79}$ See Peter Doskoch, The Safest Sex, Psychol. TODAY, Sept./Oct. 1995, at 46, 48 (citing research revealing that women who report submission fantasies have no actual interest in being raped and that the fantasies are qualitatively different from real-life rape).

${ }^{80}$ For a discussion of how the common law has tended to perpetuate this stereotype, see Susan Estrich, Rape, 95 YaLE L.J. 1087, 1094-1132 (1986).
} 


\section{A. Rape Victims and Hysteria}

Although it has been excluded from the official handbook of psychiatric diagnoses since $1952,{ }^{81}$ hysteria remains a frequently used diagnosis in the courtroom. Hysteria was historically a woman's disease; the etymology of "hyster-" refers to the uterus. ${ }^{82}$ At least since the Victorian era, hysteria has been associated with a woman's repressed sexual desire. ${ }^{83}$ Symptoms of hysteria have changed with the times. It was associated with witchcraft in the Middle Ages ${ }^{84}$ with feminine frailty in the Victorian era, ${ }^{85}$ and with physical symptoms, including blindness and paralysis, at the start of the medicalized twentieth century. ${ }^{86}$ In all cases, hysteria is marked by self-destructive, attention-seeking behavior. $^{87}$ Because the disease lacks verifiable physical symptoms, it often seems phony.

Sigmund Freud explicitly linked hysteria with fabrications of sexual assault when he publicly denounced the "seduction theory" of hysteria. ${ }^{88}$ He rejected the idea that his female patients' hysterical symptoms resulted from a history of sexual abuse (which is what they had reported to him) and posited instead that "they were only phantasies which my patients had made up." ${ }^{, 89}$ Although the professional community of psychologists and psychiatrists no longer recognizes hysteria as a mental disorder, it is an easy intuitive leap for a lay jurist to go from the first insinuation of mental illness to the stereotypical hysterical woman.

One problem with the introduction of evidence of psychological problems is that the legal system has not kept up with developments in

${ }^{81}$ Comm. On Nomenclature \& Statistics, Am. Psychiatric Ass'N, DiagnostiC AND STATISTICAL MANUAL: MENTAL DisORDERS (1952).

${ }^{82}$ RANDOM House Webster's UnABRIDGEd Dictionary 945 (2d ed. 1998).

83 See, e.g., Ilza Veith, Hysteria: The History OF A Disease 201 (1965) ("Because women were by nature more sensitive in their emotional structure than men and being compelled by convention to repress sexual needs, they were therefore far more susceptible to hysteria.").

${ }^{84} \mathrm{Id}$. at 55-73.

${ }^{85}$ Id. at $199-220$.

${ }^{86} I d$. at 182, 235.

${ }^{87}$ See MiCALE, supra note 11, at 68 ("The wildly shifting physical symptomatology of the disease was thought by many observers to mirror the irrational, capricious, and unpredictable nature of Woman.").

${ }^{88}$ Sigmund Freud, An Autobiographical Study, in THE FreUd REAdER, supra note 1, at 3, 20-21.

${ }^{89} I d$. at 21. 
psychology and psychiatry. North Carolina's rape shield law almost perfectly cites the bygone notion that women are likely to fantasize rape scenarios and confuse them with reality. ${ }^{90}$ When a court entertains testimony about the victim's capacity to fantasize about sex-and this is not only a North Carolinian phenomenon-it is implicitly endorsing the notion that women who fantasize about sex are mentally ill and therefore more likely to be unable to distinguish between fantasy and reality. ${ }^{91}$

\section{B. General Stigma of Mental Illness}

Oblique references to outdated notions of women's psychological make-up are a more subtle variant of the larger problem, which is that many people have distinct, and distinctly incorrect, ideas about mental health. One common misperception that may affect jury reasoning is the incorrect idea that mental health treatment is an aberration. Mental health treatment, once the province of the very wealthy or the very disturbed, was accessed by an estimated $13 \%$ of the American adult population in 2002. ${ }^{92}$ In fact, $17 \%$ of women sought treatment of some kind in 2002. ${ }^{93}$ In addition, over $10 \%$ of American adults received some kind of prescription medication for mental health reasons in 2002, with a large majority of these receiving exclusively outpatient treatment. ${ }^{94}$

${ }^{90}$ N.C. GEN. STAT. $\$ 8 C-1$, Rule 412(b) (4) (2003) (allowing the sexual behavior of the complainant and expert psychiatrist testimony about that behavior to be admitted as evidence where "complainant fantasized or invented the sexual acts charged").

${ }^{91}$ See, e.g., State v. Simpson, CR. A. Nos. IN-89-03-1657R1, IN-89-03-1658R1, IN-8912-0485R1, IN-89-12-0487-RI, 1996 WL 453454, at*4 (Del. Super. Ct. June 19) (permitting testimony about the victim's "capability to graphically fantasize about sexual matters”), aff'd, 683 A.2d 60 (Del. 1996); State v. Kelekolio, 849 P.2d 58, 78 (Haw. 1993) (permitting evidence of complainant's "habitual propensity to fantasize sexually" where the defendant has laid the proper foundation).

92 OfFice of ApPlied Studies, DeP'T OF Health \& Human Servs., Results From The 2002 National Survey on Drug USE AND Health: NATional Findings 74 (2003), available at http://oas.samhsa.gov/nhsda/2k2nsduh/2k2sofw.pdf [hereinafter 2002 OAS SURVEY]. Note that these are conservative numbers, as the number of people who access mental health treatment in a year is less than the number of people with mental or emotional problems. Access is constrained by factors such as poverty, lack of health insurance, willingness to seek treatment, and other barriers.

${ }^{93} I d$. There are a variety of reasons for the gender discrepancy in mental health treatment, including different attitudes toward psychotherapy, as well as the high rate of depression among women, estimated to be anywhere from ten to twenty-five percent of the adult female population. DSM-IV-TR, supra note 12, at 372.

2002 OAS SURVEY, supra note 92, at 74. 
When a defense lawyer questions the complainant about her history of treatment for mental or emotional problems, the natural implication is that she is unbalanced or crazy, and thus she is an unreliable witness. In fact, many high-functioning individuals are treated for disorders-e.g., mood disorders or anxiety disorders- that have no effect on credibility. Expert testimony may not be able to cure the problem, as the presence of the victim's psychiatrist or even of her physical file may be so prejudicial as to overshadow the testimony of the expert.

\section{Misunderstanding Patient Files}

When a judge or a defense lawyer reviews a complainant's mental health records, there are some basic tenets of psychotherapy that may skew the interpretation of the file. I will briefly discuss three of the issues surrounding this problem. First, most insurance plans will not pay the therapist until she diagnoses the patient. Therefore, patients who would have remained undiagnosed-and perhaps do not fall into a diagnostic category-are given actual labels such as generalized anxiety disorder or dysthymia (mild depression). Second, a therapist's own philosophical orientation, e.g., psychodynamic (traditionally a Freudian or Jungian approach) or cognitive-behavioral, can affect the file. A psychodynamic therapist is much more likely to include lengthy family histories, free-associations, and dreams. ${ }^{95} \mathrm{~A}$ cognitive-behavioral therapist is more likely to record more information pertaining to the patient's current functioning and the presence of inappropriate or maladaptive behaviors. ${ }^{96}$ This leads to the third problem: as a kind of psychological safe space, a therapy patient is permitted and perhaps encouraged to discuss fantasies, imagine hypothetical scenarios, or enact unlikely role-plays. What may look like a smoking gun to a defense lawyer could be appropriate exploration in a therapy session.

${ }^{95}$ See Textbook of Clinical Psychiatry, supra note 13, at pt. III (describing methods in different clinical approaches).

${ }^{96} I d$. 


\section{Misused Psychology In The Courtroom: THREE COMMON EXAMPLES}

Courts have often permitted discussion of clinical-sounding terms that carry the weight of science but lack any foundation in psychological understanding.

\section{A. Pathological Lying}

One frequent issue is the defendant's accusation that the rape victim is a "pathological liar." cal" is "disease[d]"; ${ }^{98}$ the inference that a person is pathological necessarily calls into question mental stability and, in the case of pathological lying, the suggestion that she is unable to control her lying. In fact, the terminology is even criticized in psychology literature because of its confusing connotations. ${ }^{99}$ Although the concept of lying "pathologically" has been incorporated into common usage, it is not a psychiatric diagnosis. ${ }^{100}$ When researchers are confronted with the phenomenon of inappropriate and repeated lying behavior, it is usually as a symptom of another psychopathological diagnosis. ${ }^{101}$

\section{B. Suicide Threats}

One recurring theme in rape defenses is the suicidal complainant. In 1979, a Kentucky defendant was able to establish in an avowal that the alleged victim had been committed to a psychiatric hospital after attempting suicide. ${ }^{102}$ A Florida court refused to sustain a defense mo-

${ }^{97}$ See, e.g., People v. Rath, 44 P.3d 1033, 1036 (Colo. 2002) (en banc) (noting the defense's assertion that the accuser is a "pathological liar"); People v. Love, 762 N.Y.S.2d 162, 167 (App. Div.) (same), leave to appeal denied, 801 N.E.2d 430 (N.Y. 2003).

${ }^{98}$ RANDOM House Webster's UnABRIDGED Dictionary 1421 (2d ed. 1998).

${ }^{99}$ See Bryan H. King \& Charles V. Ford, Letter to the Editor, Pseudologia Fantastica, 144 AM. J. PSYCHIATRY 970, 970 (1987) (distinguishing between pathological lying and the separate condition of pseudologia).

${ }^{100}$ See DSM-IV-TR, supra note 12 (excluding "pathological lying" as a psychiatric diagnosis).

${ }_{101}$ See, e.g., Scott Snyder, Pseudologia Fantastica in the Borderline Patient, 143 AM. J. PSYCHIATRY 1287, 1287-89 (1986) (discussing lying in patients with borderline personality disorder); Rosalie Wells, A Fresh Look at the Muddy Waters of Psychopathy, 63 PSYCHOL. REP. 843, 843-54 (1988) (discussing pathological lying in individuals diagnosed as psychopaths).

${ }^{102}$ Wagner v. Commonwealth, 581 S.W.2d 352, 355 (Ky. 1979) (holding that the psychiatric hospitalization and memory-affecting shock treatments the complaining witness received were relevant to her credibility), overruled on other grounds by Estep v. 
tion for psychiatric examination for a victim who, among other charges, had "been the victim of domestic violence at the hands of a former live-in boyfriend" and "had attempted suicide in the past."103 In a 2000 Louisiana case, a defendant was permitted to cross-examine the complaining witness as to her mental health history, including a suicide attempt and her "manipulative nature." ${ }^{\text {"104 }}$ In 1997, an unpublished opinion from the Delaware Family Court reasoned that

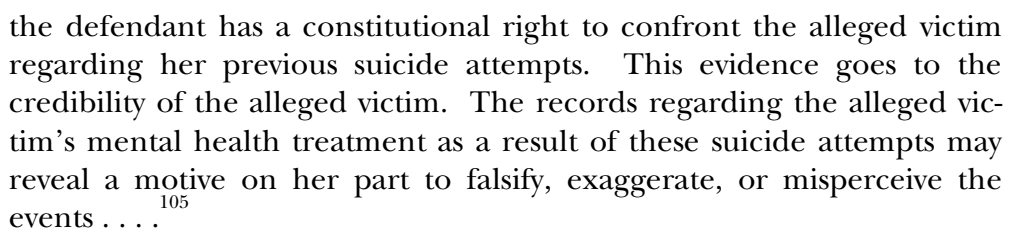
regarding her previous suicide attempts. This evidence goes to the credibility of the alleged victim. The records regarding the alleged victim's mental health treatment as a result of these suicide attempts may reveal a motive on her part to falsify, exaggerate, or misperceive the events ....

Suicide is normally symptomatic of severe depression, which may be emotionally crippling for the sufferer but arguably has no effect on credibility. It is a mood disorder and does not usually have psychotic or delusional side effects. ${ }^{106}$ For this reason, many courts find evidence of mental health treatment for depression to be inadmissible because it is irrelevant. ${ }^{107}$

The implicit message when a court permits evidence of prior suicide attempts is not that the defendant is depressed, but that she is willing to be destructive in order to get attention. ${ }^{108}$ From the point of view of a psychologist, the judge admitting the history of suicide (without knowing the terminology) is allowing the possibility that the complainant suffers from borderline or histrionic personality disor-

Commonwealth, 663 S.W.2d 213 (Ky. 1983).

${ }^{103}$ Camejo v. State, 660 So. 2d 242, 243 n.1 (Fla. 1995) (per curiam).

${ }^{104}$ State v. Wilkinson, 772 So. 2d 758, 768-69 (La. Ct. App. 2000) (stating that since the defendant was allowed to cross-examine the witness at trial on her mental health, the defendant was not prejudiced by the exclusion of the witness's medical records).

State v. K., No. JN96-2161, 1997 WL 295680, at *3 (Del. Fam. Ct. Mar. 17, 1997).

${ }^{106}$ See DSM-IV-TR, supra note 12, at 349-56 (identifying features of major depressive episode of the mood disorder generally known as depression).

${ }^{107}$ See, e.g., State v. Buckley, 325 N.W.2d 169, 170, 172 (N.D. 1982) (accepting expert testimony that a diagnosis of depression does not raise questions about "competency or ability to accurately recall and truthfully relate events'" (quoting expert's affidavit)).

${ }^{108}$ In essence, the Louisiana defendant was trying to prove his accuser's manipulative nature in order to show that her accusations were such an attempt to get attention. See Wilkinson, 772 So. $2 \mathrm{~d}$ at 768 (stating that the defendant claimed that the complainant was "likely to fabricate the story of a rape"). 
der, not depression. ${ }^{109}$ A suicide attempt is distinct from a suicide threat; threats are more common to borderline and histrionic personality disorders. ${ }^{110}$ A person who threatens suicide is able to solicit positive attention without any risk of injury. ${ }^{111}$ Only an extremely cavalier, not to mention cynical, approach to a suicide attempt would categorize it as a manipulative ploy for attention.

\section{Post-Traumatic Stress Disorder}

Another common and often misguided attempt to introduce psychiatric evidence occurs when the alleged victim has been sexually abused or assaulted previously. This is distinct from the scenario in which the complainant has previously claimed, perhaps falsely, that she was raped. When the complainant previously has been the victim of sexual assault, the defense may claim that the traumatic effects of the prior assault left her unable to distinguish between that assault and the consensual sex that she was having with the defendant. Although this sounds like a relatively small problem-what are the chances the same woman will be raped twice?-in fact it is relatively common. Studies indicate there is a high incidence of revictimization. $^{112}$

The implicit theory of courts in permitting evidence of a complainant's prior victimization is what one author calls "spurious factors." 113 The theory is essentially that women who have been sexually assaulted are not more likely to become victims again; rather, they are either more likely to report than other victims, or, more relevant to

${ }^{109}$ Borderline and histrionic personality disorders are akin to modern-day diagnoses of hysteria without the psychosomatic symptoms. Both disorders are characterized by a need for attention, and borderline personality disorder in particular is characterized by frequent suicide threats. DSM-IV-TR, supra note 12, at 706-14 (identifying features of borderline and historionic personality disorders).

${ }^{110} \mathrm{Id}$.

${ }^{111}$ Paul H. Soloff et al., Self-Mutilation and Suicidal Behavior in Borderline Personality Disorder, 8 J. PERSONALITY DISORDERS 257 (1994).

${ }^{112}$ See, e.g., Terri L. Messman \& Patricia J. Long, Child Sexual Abuse and Its Relationship to Revictimization in Adult Women: A Review, 16 Clinical PSYCHOL. Rev. 397, 414 (1996) (concluding that "between $16 \%$ and $72 \%$ of women who experienced sexual abuse as children are likely to be revictimized"); Susan B. Sorenson et al., Repeated Sexual Victimization, 6 Violence \& Victims 299, 305 (1991) (finding that $67 \%$ of sexual assault victims in a Los Angeles study had been sexually assaulted previously).

${ }^{113}$ Kimberly Hanson Breitenbecher, Sexual Revictimization Among Women: A Review of the Literature Focusing on Empirical Investigations, 6 AgGRESSION \& VIOLENT BEHAV. 415,419 (2001). 
the court, they are more likely to perceive later encounters as nonconsensual. ${ }^{114}$ Courts often allow evidence of prior sexual victimization on the theory that it may cause confusion between the two events.

In New Hampshire, for example, the state supreme court has ruled that the rape shield law applies only to evidence of previous consensual intercourse but that the defense may bring in evidence of prior sexual victimization. ${ }^{115}$ In the California case People v. Espinoza, the defense counsel claimed that the complainant's "sexual acting out behavior must have been caused by 'trauma of a sexual nature occurring over a long period of time ... [which] would destroy [her] ability to distinguish between her sexual wishes and fears and her ability to accurately assess sexual issues." "'16 In State v. McHolland, a Connecticut court permitted the defense counsel to introduce the complainant's redacted psychiatric records under the theory that during her consensual sex with the defendant, she flashed back to a prior sexual assault and "'freaked out.","17

Post-traumatic stress disorder (PTSD), most commonly associated with veterans of war, has recently been reconceived as two distinct phenomena: one is an acute reaction and the other is a chronic pathology. ${ }^{118}$ PTSD stemming from sexual assault falls into the former category. ${ }^{119}$ For most victims of a sexual assault, subsequent PTSD symptoms drop off sharply after three months and have all but disappeared within a year. ${ }^{120}$

${ }^{114} I d$. at 419-20 (describing the "spurious factors" theory and noting that it has not been supported by available empirical evidence).

${ }^{115}$ State v. Cox, 575 A.2d 1320, 1322-23 (N.H. 1990) (stating that evidence of prior nonconsensual sex could be admissible, provided its probative value is greater than its prejudicial effect).

${ }^{116} 116$ Cal. Rptr. 2d 700, 715 (Ct. App. 2002) (quoting defense motion).

117800 A.2d 667, 671, 674 (Conn. App. Ct. 2002) (quoting defense motion) (affirming trial court's admission of evidence on the victim's history of auditory and visual hallucinations).

${ }^{118}$ See David P. Valentiner et al., Coping Strategies and Posttraumatic Stress Disorder in Female Victims of Sexual and Nonsexual Assault, $105 \mathrm{~J}$. ABNORMal Psychol. 455, 455 (1996) ("Thus, acute PTSD reaction has been distinguished from chronic PTSD.").

${ }^{119} I d$. ("[T] rauma researchers have recognized that these acute reactions are a normative response to an assault and that most individuals who suffer from traumarelated symptoms show a marked decrease in those symptoms without clinical intervention .....").

${ }^{120}$ See, e.g., Gail Steketee \& Edna B. Foa, Rape Victims: Post-Traumatic Stress Responses and Their Treatment: A Review of the Literature, $1 \mathrm{~J}$. ANXIETY DISORDERS 69, 72-73 (1987) (citing studies indicating that social and sexual functions that are disrupted immediately after a rape tend to return to pre-incident levels within a matter of 
The primary problem of courts, though, is not an overdiagnosis of PTSD in rape complainants (although that may be a problem of expert witnesses). The problem is a misconception of the nature of PTSD. Among other symptoms, one criterion for PTSD is the presence of "intrusions," or flashbacks. ${ }^{121}$ This, presumably, is what courts and defense counsel are referring to when they speak of "confusing" the prior rape with the present interaction. However, this is an incorrect conception of intrusion. A flashback, however consuming and painful, is not a hallucination. PTSD is an anxiety disorder, not a psychotic disorder. ${ }^{122}$ There is an important distinction to be made between intrusion symptoms and actual delusions. The difference is as follows: a person who "re-experiences" a previous traumatic event with these kinds of intrusions is aware of their pathological nature. For this reason, PTSD sufferers will avoid any stimulus likely to provoke such an attack. On the other hand, a person suffering from a psychotic delusion lacks insight into the nature of the problem-in other words, she believes what she sees or hears to be "real." Although rape victims may be more likely to be wary of men or sexual situations because of their past experience, there is no evidence that they experience confusion between the traumatic flashbacks and contemporaneous romantic encounters.

It is a particularly cruel and unnecessary punishment to the victim unfortunate enough to have been raped more than once in her life to subject her to extra questioning about her prior victimization. It is also highly prejudicial. Evidence that the complainant has been previously sexually assaulted tends to raise questions about whether or not she is "asking for it." Discrediting a witness's testimony with evidence of prior sexual victimization also recalls the notion of a "ruined" woman. Juries need to be directed away from the misogynist

\footnotetext{
months); see also Valentiner, supra note 118, at 457 ("These results support the notion that PTSD symptomatology is a normative response to assault, especially sexual assault, and suggests that most victims recover to varying degrees within three months following the assault." (citation omitted)).

${ }^{121}$ See generally Edna B. Foa et al., Arousal, Numbing, and Intrusion: Symptom Structure of PTSD Following Assault, 152 AM. J. PSYCHIATRY 116 (1995) (describing the symptoms, including intrusion, of post-traumatic stress disorder); Regina Steil \& Anke Ehlers, Dysfunctional Meaning of Posttraumatic Intrusions in Chronic PTSD, 38 BEHAV. RES. \& THERAPY 537 (2000) (describing the relationship between the severity of the disorder and the nature of the coping mechanisms for the intrusions).

${ }^{122}$ See DSM-IV-TR, supra note 12, at 463-68 (identifying features of post-traumatic stress disorder and placing it in the category of anxiety disorders).
} 
combination of early twentieth-century psychoanalytic thought and the still-common prejudices about women and sex.

\section{CONCLUSION}

The admissibility of mental health evidence to impeach a sexual assault complainant is a body of law ripe for comprehensive reform. Although some states have taken progressive positions on one or another form of psychiatric evidence, no state has adopted a coherent approach that considers mental health history as a category. Without an underlying theory applicable to psychiatric examinations as well as access to patient files, courts and prosecutors are vulnerable to the stereotypes and prejudices that have historically plagued rape prosecutions. North Carolina's law says directly what many courts seem to be relying on implicitly: women are unreliable narrators of their own sexual experience. The distinction between a psychotic and nonpsychotic condition, the relationship between the disorder and the witness' ability to recall and testify accurately, and the relative standing of the psychological research being brought to bear must be weighed. Before permitting evidence of a rape victim's mental health history or status in a rape prosecution, courts should identify-and verify-the rational relationship between the information and its ostensible evidentiary function. 